\title{
Effects of Straw Returning on Soil Physicochemical Properties and Microbial Diversity Under the Rice-crayfish Integrated System
}

\author{
Xiuxiu Zhu \\ Yangtze University \\ Chenglin Peng \\ Hubei Academy of Agricultural Sciences, Ministry of Agriculture and Rural Affairs \\ Guohan Si ( $\nabla$ siguoh@163.com ) \\ Hubei Academy of Agricultural Sciences, Ministry of Agriculture and Rural Affairs \\ Aihua Sha \\ Yangtze University \\ Jiafu Yuan \\ Hubei Academy of Agricultural Sciences, Ministry of Agriculture and Rural Affairs \\ Shujun Zhao \\ Hubei Academy of Agricultural Sciences, Ministry of Agriculture and Rural Affairs \\ Dabing Xu \\ Hubei Academy of Agricultural Sciences, Ministry of Agriculture and Rural Affairs
}

\section{Research Article}

Keywords: Effects of straw returning, soil physicochemical properties, microbial diversity , rice-crayfish integrated system

Posted Date: October 27th, 2021

DOI: https://doi.org/10.21203/rs.3.rs-990190/v1

License: (c) (i) This work is licensed under a Creative Commons Attribution 4.0 International License. Read Full License 


\section{Abstract}

This study represents the investigation of soil physicochemical properties and microbial diversity by the Biolog ECO analysis in a 7-year field experiment using winter flooded fallow + no straw returning (W), winter flooded fallow + straw returning (WS), and winter flooded fallow + straw returning + crayfish farming (WSC) at soil depths of 0-10 cm and 10-20 cm. Compared with the W treatment, the WS treatment has significantly more total reducing substances in the 0-10 cm layer and sucrase activity in the 0-20 cm layer. The WSC treatment has significantly more available N (AN), total $\mathrm{N}(\mathrm{TN})$ contents, acid phosphatase and sucrase activities in the 10-20 cm layer, while the $\mathrm{pH}$ value, total reducing substances, and $\mathrm{Fe}^{2+}$ content in the 0-20 cm layer was considerably lower compared with the WS treatment. Biolog ECO analysis reveals that microbial community composition in the WS and WSC treatments differs from that in the W treatment in the $0-20 \mathrm{~cm}$ layer. The WS treatment increases significantly the diversity of bacterial community and the ability of utilizing carbon sources in the 0-10 cm layer, and the species abundance of bacterial community in the 0-20 $\mathrm{cm}$ layer. Meanwhile, in the $10-20 \mathrm{~cm}$ soil layer, the WSC treatment improves the species abundance of bacterial community and the ability of utilizing carbon sources compared with the WS treatment. These results indicate that straw returning under the rice-crayfish integrated system improves soil physicochemical properties, decreases reducing substances properties, and increases soil enzyme activity and functional diversity of microbial community, thereby contributing to soil condition.

\section{Introduction}

The double-cropping of crayfish (Procambarus clarki) and rice (Oryza sativa) had been practiced in Louisiana, USA, which was introduced to China in the early 21 th century, and then the rice-crayfish integrated system was formed ${ }^{1-3}$. In the rice-crayfish integrated system, the crayfish can be allowed to live in the paddy fields, where the rice straw served as the food basis for crayfish after the rice was harvested. This system fully utilized the shallow water environment and the winter idle period of rice paddies, combined planting and aquaculture industries, and really increased farmers' income. Thus, it was seen that the rice-crayfish integrated system was great economic and social benefits. Currently, the rice-crayfish integrated system had become one of the primary cultivation models in middle and lower reaches of Yangtze River, and was performed in approximately $4.6 \times 10^{5}$ ha in the Hubei Province in 2019, China. It was significantly changed in the rice-crayfish integrated system to rice output, soil physicochemical properties, and the structure of soil microbial community ${ }^{1,4-5}$. Si et a ${ }^{6}$ found that the rice-crayfish integrated system increased soil carbon levels, and strongly affected microbial community composition and structure in the deeper layers of soil. Yuan et al showed that crayfish aquaculture in rice fields significantly improved the soil quality using a minimum data set.

It was reported that the total output of straw in China ranks first in the world ( 1.04 billion tons), with large straw returning area and wide regional distribution ${ }^{8-10}$.Straw returning, a major way of utilizing straw resources, can directly or after stacking and decomposing into soil ${ }^{11}$. Several studies had demonstrated the impact of straw returning on soil physicochemical properties, the structure of soil microbial community, and microbial activity ${ }^{12-14}$. Straw returning changed soil nutrient contents and enhanced the rice yield ${ }^{15-18}$. Yan et a ${ }^{19}{ }^{9}$ showed that rice straw returning significantly increased total organic carbon content, active soil organic carbon fractions, and soil microbial richness but did not affect the soil microbial diversity in Northeast China. In addition, $\mathrm{Bu}$ et $\mathrm{a}^{20}$ found that straw returning had a dominant effect on bacterial community composition in a 12 -year ricerice-rape rotation system. Studies had also shown that straw returning had significant effects in improving the activity levels of soil enzymes ${ }^{21-23}$. Wu et a ${ }^{24}$ showed that the straw returning increased the levels of urease, phosphatase, and invertase activities over a 5 -year period. Zhang et a ${ }^{25}$ observed that the fertilizer plus residues treatment led to higher potential activities of $\beta$-glucosidase, lignin peroxidase, and manganese peroxidase enzymes, whereas it reduced the activities of laccase enzymes in a 10-year fertilization experiment.

Compared with the conventional straw returning, the rice straw under the rice-crayfish integrated system was returned to the field in the condition of long-term flooding, which can facilitate the cultivation of crayfish. In the rice-crayfish integrated system, the crayfish can feed on plant debris, and relate microbe produced during the flooded decomposition of straw. Meanwhile, the rapid decomposition of straw can be promoted by the excrement produced by crayfish during its growth. Therefore, these above phenomena may change soil physicochemical properties and microbial diversity. Nowadays, studies related to rice straw returning in China were primarily based in rice cropping rotation or double rice cropping ${ }^{18,26-27}$. Some studies also focused on effect of gas emissions in the integrated rice-crayfish farming system, such as $\mathrm{CH}_{4}, \mathrm{~N}_{2} \mathrm{O}$, and $\mathrm{NH}_{4}{ }^{28-29}$. However, there were few reports on the effects of straw returning on soil physicochemical properties and microbial diversity under the rice-crayfish integrated system. The aims of this paper were (a) to examine the changes of soil physicochemical properties, reducing substances properties, enzyme activity, and microbial community structure in the rice-crayfish integrated system and (b) to analyze the relationships between these changes under straw returning to provide reference for the exploration of improving soil fertility in the rice-crayfish integrated system and deliver theoretical guidance for maintaining healthy and sustainable agricultural ecosystem.

\section{Results}

\section{Soil physicochemical properties analysis}

As shown in Table 1, the soil total organic carbon (TOC), available nitrogen (AN), available phosphorus (AP), available potassium (AK), and the total $\mathrm{P}$ (TP) contents decreased with increasing soil depth under three treatments. The pH value of the $0-20 \mathrm{~cm}$ layer was considerably lower in the WSC 
treatment than that in the WS treatment. Meanwhile, the AN and the total N (TN) contents of the $10-20$ cm layer were significantly higher in the WSC treatment than those in the WS treatment.

\section{Table 1}

Soil physicochemical properties under different treatments. W, winter flooded fallow + no straw returning; WS, winter flooded fallow + straw returning; WSC, winter flooded fallow + straw returning + crayfish farming. Means with different letters for the same property in the same soil layer indicate significant differences at $P<0.05$. Values are means \pm standard errors.

\begin{tabular}{|c|c|c|c|c|c|c|c|c|c|}
\hline $\begin{array}{l}\text { Soil } \\
\text { depths }\end{array}$ & & $\mathrm{pH}$ & $\begin{array}{l}\text { Total } \\
\text { organic } \\
\text { carbon }\end{array}$ & Available N & Available P & Available K & Total N & Total P & Total K \\
\hline$(\mathrm{cm})$ & & & $\left(\mathrm{g} \cdot \mathrm{kg}^{-1}\right)$ & $\left(\mathrm{mg} \cdot \mathrm{kg}^{-1}\right)$ & $\left(\mathrm{mg} \cdot \mathrm{kg}^{-1}\right)$ & $\left(\mathrm{mg} \cdot \mathrm{kg}^{-1}\right)$ & $\left(\mathrm{g} \cdot \mathrm{kg}^{-1}\right)$ & $\left(\mathrm{g} \cdot \mathrm{kg}^{-1}\right)$ & $\left(g \cdot \mathrm{kg}^{-1}\right)$ \\
\hline \multirow[t]{3}{*}{$0-10$} & W & $6.81 \pm 0.06 a$ & $18.20 \pm 0.12 a$ & $114.88 \pm 4.42 b$ & $11.16 \pm 0.83 a$ & $197.05 \pm 4.88 a$ & $2.50 \pm 0.01 a$ & $0.67 \pm 0.02 a$ & $23.01 \pm 0.16 a$ \\
\hline & WS & $6.84 \pm 0.04 a$ & $18.49 \pm 0.51 a$ & $127.00 \pm 3.45 \mathrm{ab}$ & $12.79 \pm 0.16 a$ & $205.52 \pm 5.08 a$ & $2.56 \pm 0.01 a$ & $0.68 \pm 0.00 a$ & $23.12 \pm 0.21 a$ \\
\hline & WSC & $6.42 \pm 0.03 b$ & $19.56 \pm 0.87 a$ & $136.04 \pm 4.24 a$ & $12.01 \pm 0.75 a$ & $194.09 \pm 12.25 a$ & $2.55 \pm 0.07 a$ & $0.67 \pm 0.02 a$ & $23.00 \pm 0.50 a$ \\
\hline \multirow[t]{3}{*}{$10-20$} & W & $6.98 \pm 0.01 a$ & $16.66 \pm 0.56 a$ & $105.12 \pm 4.95 \mathrm{ab}$ & $10.61 \pm 0.24 a$ & $171.23 \pm 5.08 a$ & $2.18 \pm 0.03 b$ & $0.61 \pm 0.01 a$ & $23.18 \pm 0.30 a$ \\
\hline & WS & $6.91 \pm 0.03 a$ & $16.32 \pm 0.37 a$ & $89.43 \pm 2.07 b$ & $10.29 \pm 0.64 a$ & $178.00 \pm 2.96 a$ & $2.21 \pm 0.04 b$ & $0.62 \pm 0.01 a$ & $23.14 \pm 0.32 a$ \\
\hline & WSC & $6.73 \pm 0.05 b$ & $16.42 \pm 0.62 a$ & $108.93 \pm 5.44 a$ & $11.05 \pm 0.85 a$ & $185.62 \pm 1.53 a$ & $2.62 \pm 0.15 a$ & $0.64 \pm 0.01 a$ & $23.03 \pm 0.17 a$ \\
\hline
\end{tabular}

\section{Soil reducing substances properties analysis}

Soil total reducing substances, $\mathrm{Fe}^{2+}$, and $\mathrm{Mn}^{2+}$ contents increased with increasing soil depth (Table 2). Soil Fe ${ }^{2+}$ content in the $0-20 \mathrm{~cm}$ layer, Soil $\mathrm{Mn}^{2+}$ content in the 0-10 cm layer, and total reducing substances in the 0-20 cm layer was significantly lower in the WSC treatment than those in the WS treatment $(P<0.05)$. Meantime, the soil total reducing substances of the $0-10 \mathrm{~cm}$ layer was significantly higher in the WS treatment than that in the $\mathrm{W}$ treatment by $28.5 \%(P<0.05)$.

\section{Table 2}

Soil reducing substances properties under different treatments. W, winter flooded fallow + no straw returning; WS, winter flooded fallow + straw returning; WSC, winter flooded fallow + straw returning + crayfish farming. Means with different letters for the same property in the same soil layer indicate significant differences at $P<0.05$. Values are means \pm standard errors.

\begin{tabular}{|lllll|}
\hline Soil depths(cm) & & $\mathrm{Fe}^{2+}\left(\mathrm{cmol}^{\mathrm{kg}} \mathrm{kg}^{-1}\right)$ & $\mathrm{Mn}^{2+}\left(\mathrm{cmol} \cdot \mathrm{kg}^{-1}\right)$ & $\begin{array}{l}\text { Total Reducing Substances } \\
\left(\mathrm{cmol} \cdot \mathrm{kg}^{-1}\right)\end{array}$ \\
\hline $0-10$ & & & & $1.921 \pm 0.036 \mathrm{~b}$ \\
& W & $1.220 \pm 0.140 \mathrm{ab}$ & $0.084 \pm 0.007 \mathrm{ab}$ & $2.469 \pm 0.148 \mathrm{a}$ \\
\hline WS & $1.498 \pm 0.108 \mathrm{a}$ & $0.095 \pm 0.002 \mathrm{a}$ & $1.881 \pm 0.121 \mathrm{~b}$ \\
& WSC & $0.778 \pm 0.033 \mathrm{~b}$ & $0.074 \pm 0.002 \mathrm{~b}$ & $4.683 \pm 0.402 \mathrm{a}$ \\
& W & $1.670 \pm 0.063 \mathrm{a}$ & $0.085 \pm 0.001 \mathrm{a}$ & $3.934 \pm 0.084 \mathrm{a}$ \\
\hline
\end{tabular}

\section{Soil enzyme activity analysis}

Soil enzyme activity decreased with increasing soil depth (Table 3). Soil sucrase and acid phosphatase activities showed an increasing trend in the WSC and WS treatments compared with the W treatment in all of the layers examined. Soil sucrase activity was significantly higher in the WS treatment than that in the $\mathrm{W}$ treatment $(P<0.05)$. Meantime, soil sucrase and acid phosphatase activities in the $10-20 \mathrm{~cm}$ layer were higher in the WSC treatment than those in the WS treatment by $44.4 \%$ and $32.2 \%$, respectively. However, there was no significant difference in soil urease activity among different treatments in 0-20 cm layer.

Table 3

Soil enzyme activity analysis under different treatments. W, winter flooded fallow + no straw returning; WS, winter flooded fallow + straw returning; WSC, winter flooded fallow + straw returning + crayfish farming. Means with different letters for the same property in the same soil layer indicate 
significant differences at $P<0.05$. Values are means \pm standard errors.

\begin{tabular}{|lllll|}
\hline Soil depths $(\mathrm{cm})$ & & $\begin{array}{l}\text { Acid phosphatase } \\
\left(\mathrm{mg} \cdot \mathrm{phenol} \cdot \mathrm{g}^{-1} \mathrm{soil} \cdot 24 \mathrm{~h}^{-1}\right)\end{array}$ & $\begin{array}{l}\text { Urease } \\
\left(\mathrm{mg} \cdot \mathrm{NH}_{3}-\mathrm{N} \cdot \mathrm{g}^{-1} \mathrm{soil} \cdot 24 \mathrm{~h}^{-1}\right)\end{array}$ & $\begin{array}{l}\text { Sucrase } \\
\left(\mathrm{mg} \cdot \mathrm{glucose} \cdot \mathrm{g}^{-1} \mathrm{soil}^{2} \cdot 24 \mathrm{~h}^{-1}\right)\end{array}$ \\
\hline $0-10$ & W & $47.38 \pm 3.19 \mathrm{~b}$ & $2.11 \pm 0.08 \mathrm{a}$ & $131.60 \pm 6.16 \mathrm{~b}$ \\
& WS & $54.73 \pm 2.72 \mathrm{ab}$ & $2.12 \pm 0.03 \mathrm{a}$ & $211.41 \pm 4.44 \mathrm{a}$ \\
\hline $10-20$ & WSC & $61.71 \pm 2.84 \mathrm{a}$ & $2.01 \pm 0.06 \mathrm{a}$ & $222.16 \pm 6.79 \mathrm{a}$ \\
& W & $37.49 \pm 1.40 \mathrm{~b}$ & $2.11 \pm 0.08 \mathrm{a}$ & $122.39 \pm 5.93 \mathrm{c}$ \\
& WS & $40.43 \pm 2.80 \mathrm{~b}$ & $2.12 \pm 0.06 \mathrm{a}$ & $159.03 \pm 6.64 \mathrm{~b}$ \\
\hline
\end{tabular}

\section{Soil functional diversity of microbial community analysis}

The soil average well color development (AWCD) value is one of the indices to judge the total carbon utilization ability of microbial community, reflecting the soil microbial activity and the diversity of physiological functions of microbial community ${ }^{30}$. With the increasing duration of culture (Figure 1), the utilization degree of different carbon source increased gradually. In the $0-20 \mathrm{~cm}$ layer, the slope of the AWCD value was the highest at 24-120 $\mathrm{h}$ of culture, indicating that carbon source metabolic activity of soil microbes was the highest at this stage, and then a stable stage period was entered. During hours 72-192 in Fig. 1, the soil AWCD value in the WS treatment was higher than that in the W treatment, and the AWCD value of the WSC treatment was higher than that in the WS treatment in the $0-20 \mathrm{~cm}$ layer. This showed that the WSC and WS treatments increased microbial activity in the $0-20 \mathrm{~cm}$ layer.

The Shannon index reflects the diversity of bacterial community, with a higher index indicating the stronger the diversity of bacterial community ${ }^{31-32}$. The Simpson index reflects the changes in the population of each species, with a higher index indicating the position of dominant species more prominent ${ }^{33}$. The Mclntosh index is an index to measure the community species consistency, with an increased degree of carbon source utilization, and consequently an increased Mclntosh index ${ }^{34}$. Table 4 showed that at $96 \mathrm{~h}$ of culture in the Biolog ECO microplate, those indices were significant difference in the AWCD value in the 0-20 cm layer among the W, WS, and WSC treatments. In the 0-10 cm layer, the Shannon, Simpson, and McIntosh indices in the WS treatment were significantly higher than those in the W treatment. However, there were no significant difference in Shannon, Simpson, and McIntosh indices of the soil microbial community between the WSC and WS treatments. In the 10-20 cm layer, the Simpson index in the WS treatment had a significant increased compared with the W treatment. The Simpson, and Mclntosh indices in the WSC treatment were significantly higher than those in the WS treatment. Therefore, the WS treatment increased significantly the diversity and species abundance of bacterial community in the $0-10 \mathrm{~cm}$ layer, the ability of utilizing carbon sources in the $0-10 \mathrm{~cm}$ layer, and the species abundance of bacterial community in the 10-20 cm layer. The species abundance of bacterial community, and the ability of utilizing carbon sources were increased significantly in the WSC treatment in the $10-20 \mathrm{~cm}$ layer.

\section{Table 4}

Functional diversity index of the soil microbial community under different treatments. W, winter flooded fallow + no straw returning; WS, winter flooded fallow + straw returning; WSC, winter flooded fallow + straw returning + crayfish farming. Means with different letters for the same property in the same soil layer indicate significant differences at $P<0.05$. Values are means \pm standard errors.

\begin{tabular}{|llllll|}
\hline Soil depths $(\mathrm{cm})$ & & AWCD of $96 \mathrm{~h}$ & Shannon Index & Simpson Index & Mclntosh Index \\
\hline $0-10$ & W & $0.87 \pm 0.06 \mathrm{~b}$ & $2.89 \pm 0.03 \mathrm{~b}$ & $0.939 \pm 0.002 \mathrm{~b}$ & $6.68 \pm 0.10 \mathrm{~b}$ \\
\cline { 2 - 6 } & WS & $1.27 \pm 0.02 \mathrm{a}$ & $3.11 \pm 0.05 \mathrm{a}$ & $0.951 \pm 0.003 \mathrm{a}$ & $8.71 \pm 0.08 \mathrm{a}$ \\
\hline WSC & $1.42 \pm 0.03 \mathrm{a}$ & $3.21 \pm 0.02 \mathrm{a}$ & $0.957 \pm 0.001 \mathrm{a}$ & $9.08 \pm 0.04 \mathrm{a}$ \\
& W & $0.51 \pm 0.09 \mathrm{~b}$ & $2.50 \pm 0.20 \mathrm{~b}$ & $0.897 \pm 0.006 \mathrm{c}$ & $4.81 \pm 0.48 \mathrm{~b}$ \\
& WS & $0.69 \pm 0.10 \mathrm{~b}$ & $2.73 \pm 0.17 \mathrm{ab}$ & $0.922 \pm 0.004 \mathrm{~b}$ & $5.40 \pm 0.65 \mathrm{~b}$ \\
& WSC & $1.23 \pm 0.13 \mathrm{a}$ & $3.16 \pm 0.04 \mathrm{a}$ & $0.954 \pm 0.002 \mathrm{a}$ & $8.10 \pm 0.69 \mathrm{a}$ \\
\hline
\end{tabular}

\section{Analysis of soil microbe carbon source utilization}


Based on the types of carbon sources in the Biolog ECO microplate, the 31 kinds of carbon sources were divided into carbohydrates, carboxylic acids, amino acids, phenols, amines and polymers. The changes in the AWCD values of microbial carbon source utilization at $96 \mathrm{~h}$ of three

treatments were analyzed.

As shown in Fig. 2, with increasing soil layer depth, the soil microbial utilization rate of carbohydrates, carboxylic acids, amino acids, phenols, amines, and polymers showed a gradual decreasing trend among three treatments. Compared with the W treatment, there were a huge increase in the WS treatment among the utilization rates of carbohydrates, carboxylic acids, amino acids, amines and polymers in the 0-20 cm layers by 47.5 $52.4 \%, 31.4-63.0 \%, 27.9-45.7 \%, 1.4-51.8 \%$, and $51.8-65.0 \%$, respectively. The WSC treatment also represented the same tendency in the $0-20 \mathrm{~cm}$ layers compared with the WS treatment, in which the utilization rates of phenols in the $0-10 \mathrm{~cm}$ layer and the utilization rates of carbohydrates, amino acids, and amines in the 10-20 cm layer had significant differences. Consequently, the straw returning significantly increased amino acids and polymers utilization rates in the 0-10 cm layer, carboxylic acids utilization rates in the 10-20 cm layer. The straw returning $+\mathrm{crayfish}$ farming significantly increased the utilization rates of phenols in the $0-10 \mathrm{~cm}$ layer and the utilization rates of carbohydrates, amino acids, and amines in the $10-20 \mathrm{~cm}$ layer.

\section{Interaction of physicochemical and reducing substances properties with soil enzyme activity and microbial diversity indices}

As shown in table 5 , the $\mathrm{pH}$ value, $\mathrm{Fe}^{2+}$ content, and total reducing substances had a highly significant negative correlation with the AWCD of $96 \mathrm{~h}$, acid phosphatase, sucrase, Shannon index, Simpson index, and McIntosh index. The TOC, AK, AN, and TP contents had significant positive relationship with the AWCD of $96 \mathrm{~h}$, acid phosphatase, Shannon index, Simpson index, and Mclntosh index. The TN content had also significant positive relationship with the AWCD of $96 \mathrm{~h}$, acid phosphatase, sucrase, Shannon index, Simpson index, and Mclntosh index. In addition, the AP content with the AWCD of $96 \mathrm{~h}$ and McIntosh index showed a significant direct correlation. Thus, it can be seen that the pH value and TN content had a closer relationship with soil enzymes; the $\mathrm{pH}$ value, $\mathrm{AK}, \mathrm{TN}$, and $\mathrm{Fe}^{2+}$ contents and total reducing substances had a closer relationship with the soil microbial diversity indices.

Table 5

Correlation coefficient of soil physicochemical properties, soil reducing substances properties, soil enzyme activity and microbial diversity index. * significant at $P<0.05$. ${ }^{*}$ significant at $P<0.01$.

\begin{tabular}{|c|c|c|c|c|c|c|c|}
\hline & AWCD of $96 \mathrm{~h}$ & Acid phosphatase & Urease & Sucrase & Mclntosh index & Simpson index & Shannon index \\
\hline $\mathrm{pH}$ & $-0.719^{\star *}$ & $-0.812^{\star \star}$ & 0.317 & $-0.644^{\star \star}$ & $-0.697^{\star \star}$ & $-0.702^{\star \star}$ & $-0.654^{* *}$ \\
\hline TOC & $0.503^{*}$ & $0.507^{*}$ & -0.31 & 0.256 & $0.498^{*}$ & $0.483^{*}$ & $0.514^{*}$ \\
\hline AP & $0.537^{\star}$ & 0.466 & 0.013 & 0.429 & $0.565^{*}$ & 0.442 & 0.421 \\
\hline AK & $0.712^{\star \star}$ & $0.654^{\star *}$ & 0.006 & 0.435 & $0.752^{\star \star}$ & $0.778^{\star \star}$ & $0.685^{\star \star}$ \\
\hline AN & $0.721^{\star \star}$ & $0.641^{\star *}$ & -0.321 & 0.454 & $0.727^{\star \star}$ & $0.588^{*}$ & $0.583^{*}$ \\
\hline TK & -0.259 & -0.07 & 0.014 & -0.081 & -0.258 & -0.221 & -0.346 \\
\hline $\mathrm{TN}$ & $0.748^{\star \star}$ & $0.644^{\star \star}$ & -0.416 & $0.637^{\star \star}$ & $0.762^{\star \star}$ & $0.789^{\star \star}$ & $0.668^{\star \star}$ \\
\hline TP & $0.616^{\star \star}$ & $0.572^{*}$ & -0.151 & 0.404 & $0.629^{\star \star}$ & $0.651^{\star \star}$ & $0.501^{*}$ \\
\hline $\mathrm{Fe}^{2+}$ & $-0.766^{\star *}$ & $-0.723^{\star *}$ & 0.373 & $-0.556^{*}$ & $-0.767^{\star \star}$ & $-0.781^{\star *}$ & $-0.688^{\star \star}$ \\
\hline $\mathrm{Mn}^{2+}$ & -0.132 & -0.212 & 0.093 & -0.011 & -0.148 & -0.028 & -0.034 \\
\hline Total Reducing Substances & $-0.772^{\star *}$ & $-0.780^{\star *}$ & 0.147 & $-0.540^{*}$ & $-0.770^{\star \star}$ & $-0.890^{\star *}$ & $-0.773^{\star *}$ \\
\hline
\end{tabular}

\section{Discussion}

Some studies have reported that the straw returning and the rice-crayfish integrated system increased the concentrations of elements such as $\mathrm{N}$, $\mathrm{P}$, and $\mathrm{K}^{35-36}$. In the present study, the physicochemical properties were no significant differences between the WS and the W treatments in the $0-20 \mathrm{~cm}$ layers. A possible reason was that the time of the straw returning was so short that no sufficient decomposition of the rice straw under waterlogging condition. Compared with the WS treatment, the WSC treatment had significantly higher in the AN and TN contents, supporting the findings of Yi et 
$a^{\beta 7}$. Meanwhile, the soil $\mathrm{pH}$ value decreased significantly under the WSC treatment in the $0-20 \mathrm{~cm}$ layers compared with the WS treatment. The reason for the decreased soil pH value may be the uneaten crayfish feed, the molts, excretions, and other substances produced by crayfish during their growth process, and dying crayfish, which were fermented and decomposed by bacteria under anaerobic conditions, producing a large number of organic acids and reducing soil $\mathrm{pH}$.

Soil enzyme activity is often considered an important indicator of soil quality. Urease, acid phosphatase, and sucrase were related to the N, P, and C cycles, and their activities showed an increasing trend in the WS treatment compared with the W treatment in all of the soil layers examined. Sucrase activity was significantly higher in the WS treatment than that in the W treatment in the $0-20 \mathrm{~cm}$ layers. Our results were in agreement with those of Wu et $a^{24}$. Meanwhile, compared with the WS treatment, acid phosphatase and sucrase activities were significantly higher in the WSC treatment in the 10-20 cm layer. A more important factor was the incorporation of a mass of straw to the upper soils, which can increase the microbial population ${ }^{24}$. Another factor was the crayfish digging and other activities which disturbed the surface of paddy soils and increased soil permeability, enhanced the soil nutrients and dissolved oxygen in water to reach the deep layer, thus changing the microbial activities.

Soil reducing substance is an important indicator of soil redox status, which has a significant impact on crop growth and yield ${ }^{38}$. Our study showed that the $\mathrm{Fe}^{2+}, \mathrm{Mn}^{2+}$ contents, and total reducing substances were prominently lower in the WSC treatment than those in the WS treatment after longterm waterlogging. Our results were difference with some studies ${ }^{4,39}$. The chief factor was the difference in the pilot areas. In our study, the experimental site belonged to typical waterlogged paddy in the Jianghan Plain, having strong soil reduction, and slowing organic matter decomposition, thus leading to soil gleying. However, crayfish penetrated the surface and base layers of the rice paddy soil, increasing water migration channels, and allowing the nutrients and dissolved oxygen in water to reach the base layer, thus decreasing the soil reducing substance contents here. Meanwhile, in our study, the straw returning decreased significantly the total reducing substances in the $0-10 \mathrm{~cm}$ layer. The incorporation of a mass of straw to the upper soils may be the reason, which can further deepen the anaerobic environment of the soil.

Soil microbial community functional diversity is an indicator of soil microbe community structure and function, and reflects the ecological characteristics of soil microbes ${ }^{40}$. The Biolog ECO method is a sensitive method for detecting functional changes in soil microbial community structure, and is broadly used to assess soil microbial community functional diversity ${ }^{41}$. In this study, we observed that the AWCD value of the WS and the WSC treatments always higher than those in the W treatment during all cultured time. Meanwhile, the WS treatment increased the soil microbial diversity, soil microbial richness, and the ability of utilizing carbon sources in the $0-20 \mathrm{~cm}$ layers. Those were in good agreement with those of $\mathrm{Yu}$ et $\mathrm{a}^{\mathrm{A2}}$. The reason for this was the straw returning contributed to the greater accumulation of rice residues on the soil surface, promoting the growth and proliferation of certain groups of microbes. Compared to the WS treatment, the WSC treatment increased significantly the microbial utilization rate of carbon source and the species abundance of bacterial community in the $10-20 \mathrm{~cm}$ layer. Those were consistent with the results reported by Zhu et $a A^{43}$. It may due to the reason that the crayfish activity could enhance the dissolved oxygen in water to reach the deep layer, change the availability of nutrients and oxygen, and affect microbial community structure, function, and diversity.

Research on the utilization of the different carbon sources by soil microbe could reveal detailed information about microbial community metabolism ${ }^{44}$. In this study, the results showed that the straw returning and crayfish farming had a greatly influence on the community composition of soil microbe in the $0-20 \mathrm{~cm}$ layers. The straw returning can increased the microbial populations and the crayfish farming alleviated the anaerobic situation of soil and increased aerobic bacterial community, which made the utilization of carbon sources for microbe increase at this time.

Soil microbial diversity was affected by soil type, moisture, $\mathrm{pH}$, and soil management measures ${ }^{45}$. The correlation analysis showed that the soil $\mathrm{pH}$ value, $\mathrm{AK}, \mathrm{TN}$, and $\mathrm{Fe}^{2+}$ contents and total reducing substances were significantly correlated with microbial diversity indices. Meanwhile, compared with the other two enzymes, acid phosphatase was more affected by soil physicochemical and reducing substances properties.

\section{Materials And Methods}

\section{Study area and experimental design}

The study was conducted on a 7-year-old rice-crayfish integrated system in waterlogged paddy fields at Immigrant village, Houhu Farm, Qianjiang City, Hubei Province, China $\left(112^{\circ} 41^{\prime} 32.5^{\prime \prime} \mathrm{E}, 30^{\circ} 22^{\prime} 41.2^{\prime \prime} \mathrm{N}\right)$. This area was part of the low lake areas of Jianghan plain, with the static groundwater level of $40-60 \mathrm{~cm}$ in winter, belonging to the humid climate zone of north subtropical monsoon. The average annual temperature was $16.1^{\circ} \mathrm{C}$, with a frost-free period of 246 days. The average annual rainfall was $1100 \mathrm{~mm}$. The soil type was a fluvo-aquic paddy soil, which developed from lacustrine deposit.

The field experiment started in 2014, and three treatments were set up: winter flooded fallow + no straw returning (W), winter flooded fallow + straw returning (WS) and winter flooded fallow + straw returning + crayfish farming (WSC). Each treatment was set to be repeated 3 times, with a cell area of $100 \mathrm{~m}^{2}$.

The rice cultivar of three treatments was Jianzhen 2. The use of plant in the present study complies with international, national and/or institutional guidelines. 
The way of the rice straw returning was high stubble followed by irrigation and rotary tillage before rice planting. The stubble height was about 40 $\mathrm{cm}$ and the return amount was $1900 \mathrm{~kg} \cdot \mathrm{ha}^{-1}$.

Crayfish larvae (weighing $5 \pm 2 \mathrm{~g}$ ) were stocked at a density of $9 \times 10^{4}$ larvae ha $^{-1}$, and the crayfish self-propagated inside the rice paddies. Then a proper amount of broodstock were added at this time of the year according to the actual situation. The crayfish were released into the flooded field on 25 October 2014, exactly 20 days after the rice harvest. Mature crayfish were harvested in June in the second year, and immature crayfish migrated to the peripheral trench before re-entering the rice field after field puddling, seedling planting, field drying, and re-watering. In the second season, mature crayfish were harvested before the rice harvest. In order to prevent crayfish from escaping, ditches with a width of $0.4 \mathrm{~m}$ and a depth of $1.0 \mathrm{~m}$ were set in each community, while crayfish ditches with a width of 3.0-4.0 $\mathrm{m}$ and a depth of 0.8-1.0 m were set at one side of the community, and nylon nets were also set around it.

The fertilizer amounts of the three treatments were $\mathrm{N} 150 \mathrm{~kg} \cdot \mathrm{ha}^{-1}, \mathrm{P}_{2} \mathrm{O}_{5} 36 \mathrm{~kg} \cdot \mathrm{ha}^{-1}$ and $\mathrm{K}_{2} \mathrm{O} 120 \mathrm{~kg} \cdot \mathrm{ha}{ }^{-1}$.

Before the experiment in 2014, the basic physical and chemical properties of 0-20 cm topsoil were as follows: $\mathrm{pH} 7.12$, total organic carbon (TOC) $15.33 \mathrm{~g} \cdot \mathrm{kg}^{-1}$, total nitrogen (TN) $2.36 \mathrm{~g} \cdot \mathrm{kg}^{-1}$, total phosphorus (TP) $0.45 \mathrm{~g} \cdot \mathrm{kg}^{-1}$, total potassium (TK) $19.50 \mathrm{~g} \cdot \mathrm{kg}^{-1}$, available nitrogen (AN) 129.50 $\mathrm{mg} \cdot \mathrm{kg}^{-1}$, available phosphorus (AP) $9.13 \mathrm{mg} \cdot \mathrm{kg}^{-1}$, and available potassium (AK) $178.67 \mathrm{mg} \cdot \mathrm{kg}^{-1}$.

\section{Soil sampling and storage}

Soil samples were collected on the $11^{\text {th }}$ November 2020 after the harvest using a sample auger at depths of 0-10 cm and $10-20 \mathrm{~cm}$. Sampling was conducted from five different sites within each replicate plot, and the five samples were mixed to prepare a composite sample for the plot. Immediately after sampling, visible root fragments and stones were manually removed, and the samples were mixed well and divided into two portions. One portion of fresh soil was passed through a 2-mm sieve and stored in a refrigerator at $4^{\circ} \mathrm{C}$ until its biological characteristics were analysed, and the other was air-dried and filtered in preparation for chemical characteristics analysis.

\section{Soil physicochemical properties analysis}

Soil physicochemical properties were assayed according to the methods described by $\mathrm{Bao}^{46}$. Soil $\mathrm{pH}$ was measured in a soil water mixture $(1: 2.5 \mathrm{w} / \mathrm{v})$ using a $\mathrm{pH}$ meter. The TOC content was determined by oxidation with potassium dichromate and titration with ferrous ammonium sulfate. The TN was determined by the Kjeldahl digestion method. The TP and TK were extracted and determined by the perchloric acid digestion methods and spectrophotometer protocols. The soil $\mathrm{AN}$ was converted to $\mathrm{NH}_{4}{ }^{+}$under alkaline conditions, collected in $\mathrm{H}_{3} \mathrm{BO}$ solution, and then determined by titration with standard $0.01 \mathrm{~mol} \cdot \mathrm{L}^{-1} \mathrm{H}_{2} \mathrm{SO}_{4}$. The AP was determined using the molybdenum blue method with a spectrophotometer after extraction with $0.5 \mathrm{~mol} \cdot \mathrm{L}^{-1} \mathrm{NaHCO}_{3}$ at $\mathrm{pH} 8.5$. The $\mathrm{AK}$ was determined by $1.0 \mathrm{~mol} \cdot \mathrm{L}^{-1}$ ammonium acetate extraction-flame spectrophotometry.

\section{Soil reducing substances properties analysis}

The potassium periodate colorimetry was used for $\mathrm{Mn}^{2+}$, phenanthroline colorimetry was used for $\mathrm{Fe}^{2+}$, and $\mathrm{Al}_{2}\left(\mathrm{SO}_{4}\right)_{3}$ leaching-potassium dichromate volumetric method was used for the total amount of reducing substances ${ }^{47}$.

\section{Soil enzyme activity analysis}

Enzyme activity was assayed according to the methods described by Guan ${ }^{48}$, and acid phosphatase activity was estimated by determining the amount of phenol released after incubating the samples with phenyl disodium phosphate $(0.5 \% \mathrm{w} / \mathrm{v})$ for $24 \mathrm{~h}$ at $37^{\circ} \mathrm{C}$. Urease activity was measured by determining the amount of $\mathrm{NH}_{4}{ }^{+}$released from a hydrolysis reaction after incubating the samples with urea $(10 \% \mathrm{w} / \mathrm{v})$ for $24 \mathrm{~h}$ at $37^{\circ} \mathrm{C}$, and sucrase activity was measured by determining the amount of glucose released after incubating the samples with sucrose $(8 \% \mathrm{w} / \mathrm{v})$ at $37^{\circ} \mathrm{C}$ for $24 \mathrm{~h}$.

\section{Soil functional diversity of microbial community analysis}

Soil functional diversity of microbial community was determined by the Biolog-ECO method ${ }^{49}$. The $10 \mathrm{~g}$ fresh soil was passed through a 2 mm sieve, added to $100 \mathrm{~mL} 0.85 \%(\mathrm{w} / \mathrm{v})$ sterile $\mathrm{NaCl}$ solution, and agitated for $30 \mathrm{mins}$. In the situation of bacteria free, the mixture was diluted to $10^{-3}$ with sterile $0.85 \% \mathrm{NaCl}$ solution, and an 8-channel pipette was used to add $150 \mu \mathrm{L}$ of the diluted suspension to each well of the Biolog ECO plate. Each soil sample was done in triplicate. Cultures were grown at a constant temperature of $25^{\circ} \mathrm{C}$. The absorbance at $590 \mathrm{~nm}$ was measured for each well after $24,48,72,96,120,144,168,196$, and $240 \mathrm{~h}$. 
(1) Average absorbance $(A W C D)$ can judge the total ability of microbial community to utilize carbon source.

$$
A W C D=\frac{\sum\left(A_{i}-A_{A 1}\right)}{31}
$$

In this equation, $A_{i}$ is the relative absorbance at $590 \mathrm{~nm}$ of the ith reaction well; $A_{A 1}$ is the relative absorbance of well $A 1$; wells with an $A_{i}-A_{A 1}$ value of $<0$ are set to 0 for the purpose of calculations, so that all values of $A_{i}-A_{A 1}$ are greater than or equal to 0 .

(2) Shannon index $H^{\prime}$ is used to evaluate richness.

$$
H^{\prime}=-\sum P_{i} \cdot \ln \left(P_{i}\right)
$$

Here, $\mathrm{P}_{\mathrm{i}}$ is the ratio of the relative absorbance of the ith well to the total relative absorbance of the entire sample plate.

(3) Simpson index is used to evaluate dominance index, and its variant Gini index is often used to evaluate diversity.

$$
D=1-\Sigma(P i)^{2}
$$

Here, $\mathrm{P}_{\mathrm{i}}$ is the ratio of the relative absorbance of the ith well to the total relative absorbance of the entire sample plate.

(4) Mclntosh index is a diversity index based on multi-dimensional spatial distance of community species. In fact, It is a measure of consistency.

$$
U=\sqrt{\left(\sum n_{i}^{2}\right)}
$$

Here, $n_{i}$ is the relative absorbance of the ith well.

\section{Statistical analysis}

The data were analysed using Excel 2010, SPSS software (version 22.0), and the treatment means were compared using the least significant difference test at $P<0.05$. Pearson's correlation analyses were conducted to investigate relationships between soil physicochemical properties and biological parameters. All experimental protocols involving plant materials were conducted in accordance with institutional, national, and international guidelines and legislation.

\section{Declarations}

\section{Data Availability}

The datasets generated during and/or analysed during the current study are available from the corresponding author on reasonable request.

\section{Acknowledgements}

This work was financially supported by the National Natural Science Foundation of China (42077097), the National Key Technologies R \& D Program of China (2018YFD0301305), and the Scientific and Technological Achievements Cultivation Project of Hubei Academy of Agricultural Sciences of China (2017CGPY01).

\section{Author Contributions}

X.Z., C.P., G.S., and A.S. designed the research. J.Y., S.Z., and D.X. conducted the experiments and managed the paddy fields. X.Z., C.P., and G.S. analyzed data and wrote the paper. All authors contributed to discussion of the results and the manuscript.

\section{References}


1. Chien, Y. H. \& Avault, J. W. Jr. Production of crayfish in rice fields. The Progressive Fish-Culturist42,67-71( 1980).

2. Brunson, M. W. \& Griffin, J. L. Comparison of rice-crayfish and grain sorghum-crayfish double cropping systems.Elsevier72,265-272( 1988).

3. He, Y. M. \& Zhang, T. H. Present situation and measures of rice culture of Procambarus clarkii in China. Scientific Fish Farming, 3, 1-2 (2011).).

4. Yuan, P. L., Wang, J. P., Li, C. F. \& Cao, C. G. Long-term rice-crayfish farming aggravates soil gleying and induced changes of soil iron morphology.Soil Use Manage00,1-14( 2020).

5. Si, G. H. et al. Effect of integrated rice-crayfish farming system on soil physico-chemical properties in waterlogged paddy soils. Chinese Journal of Eco-Agriculture, Jan. 25,61-68( 2017).

6. Si, G. H. et al., Changes in soil microbial community composition and organic carbon fractions in an integrated rice-crayfish farming system in subtropical China.Scientific reports7,2856( 2017).

7. Yuan, P. L. et al., Soil quality indicators of integrated rice-crayfish farming in the Jianghan Plain, China using a minimum data set.Soil \& Tillage Research204,104732( 2020).

8. Wang, Y. L. et al., Does continuous straw returning keep China farmland soil organic carbon continued increase? A meta-analysis. Journal of Environmental Management288,112391( 2021).

9. Li, H. et al.. Evaluation on the Production of Food Crop Straw in China from 2006 to 2014. BioEnergy Research10,945-957( 2017).

10. $\mathrm{He}, \mathrm{H}$. et al., Effects of nitrogen management on yield and nitrogen utilization of double cropping late rice under total rice straw incorporation. Journal of Plant Nutrition and Fertilizer20,811-820( 2014).

11. Xue, Y. H. Mechanization technology of corn straw returning.Beijing Agriculture25,39( 2010).

12. Yang, H. S. et al. The impacts of ditch-buried straw layers on the interface soil physicochemical and microbial properties in a rice-wheat rotation system. Soil \& Tillage Research202,104656( 2020).

13. Yuan, H. Z. et al., Straw and biochar strongly affect functional diversity of microbial metabolism in paddy soils. Journal of Integrative Agriculture18,1474-1485( 2019).

14. Li, Y. M. et al., Straw alters the soil organic carbon composition and microbial community under different tillage practices in a meadow soil in Northeast China.Soil \& Tillage Research208,104879( 2021).

15. Zhai, S. L. et al. Long-term ditch-buried straw return alters soil carbon sequestration, nitrogen availability and grain production in a rice-wheat rotation system.Crop and Pasture Science72,245-254( 2021).

16. Cang, B. F. et al. Effect of Light Simplified Cultivation Mode on Growth and Yield of Rice under Straw Returning Condition. E3S Web of Conferences 203, 02008 (2020).

17. Song, K. et al., Efects of tillage and straw return on water-stable aggregates, carbon stabilization and crop yield in an estuarine alluvial soil.Scientific reports9,4586( 2019).

18. Kubar, K. A. et al.. Integrative effects of no-tillage and straw returning on soil organic carbón and water stable aggregation under rice-rape rotation. Chilean journal of agricultural research78,205-215( 2018).

19. Yan, S. S. et al., Changes in soil organic carbon fractions and microbial community under rice straw return in Northeast China.Global Ecology and Conservation22,e00962( 2020).

20. Bu, R. Y. et al., Tillage and straw-returning practices effect on soil dissolved organic matter, aggregate fraction and bacteria community under rice-rice-rapeseed rotation system.Agriculture, Ecosystems and Environment 287,106681( 2020).

21. Zhang, P. et al., Effects of straw incorporation on the soil nutrient contents, enzyme activities, and crop yield in a semiarid region of China.Soil \& Tillage Research160,65-72( 2016).

22. Zhao, S. C. et al. Changes in soil microbial community, enzyme activities and organic matter fractions under long-term straw return in northcentral China.Agriculture, Ecosystems and Environment 216,82-88( 2016).

23. Yang, H. S. et al.. Long term ditch-buried straw return affects soil fungal community structure and carbon-degrading enzymatic activities in a rice-wheat rotation system.Applied Soil Ecology155,103660( 2020).

24. Wu, L. P. et al. D. Changes in soil bacterial community and enzyme activity under five years straw returning in paddy soil. European Journal of Soil Biology 100,103215( 2020).

25. Zhang, L. G. et al., Soil labile organic carbon fractions and soil enzyme activities after 10 years of continuous fertilization and wheat residue incorporation.Scientific reports 10,113118 (2020).

26. Jin, Z. Q. et al. X. Effect of straw returning on soil organic carbon in rice-wheat rotation system: A review. Food Energy Secur. 9,e200( 2020).

27. Zhu, J., Peng, H., Ji, X. H., Li, C. J. \& Li, S. N. Effects of reduced inorganic fertilization and rice straw recovery on soil enzyme activities and bacterial community in double-rice paddy soils. European Journal of Soil Biology94,103116( 2019).

28. Sun, Z. C. et al., Effects of straw returning and feeding on greenhouse gas emissions from integrated rice-crayfish farming in Jianghan Plain, China.Environmental Science and Pollution Research26,11710-11718( 2019).

29. Si, G. H. et al., Effect of Rice Straw Returning to Field on Ammonia Volatilization in Paddy Fields under the Integrated Rice-crayfish System. Journal of Ecology and Rural Environment37,360-368( 2021).

Page 9/11 
30. Zhang, H., LV, J. L., Cao, Y. F. \& Xu, W. X.Decomposition characteristics of different plant straws and soil microbial functional diversity.Acta pedologica sinica51,743-752( 2014).

31. Grice, E. A. et al., Topographical and temporal diversity of the human skin microbiome.Science (New York, N.Y.) 324,1190-1192( 2009).

32. Li, Z. P., Wu, X. C. \& Chen, B. Y. Changes in transformation of soil organic carbon and functional diversity of soil microbial community under different land use patterns. Sci. Agric. Sin. 40,1712-1721( 2007).

33. Meng, Q. J., Xu, Y. L., Li, C. J., Han, X. Z. \& Pei, X. C. Effects of different vegetation on microbial functional diversity in black soil.Chin. J. Ecol. $27,1134-1140$ (2008).

34. Xu, Q. F., Jiang, P. S., Wang, Q. Z. \& Lu, Y. T. Effects of green manure on soil microbial properties of phyllostachys pubescens stands under intensive management.Beijing For.Univ. 31,43-48( 2009).

35. Dang, K. et al., Soil research mechanism of combining straw returning with plastic film mulching to increase rice yield.Journal of Northeast Agricultural Sciences46,11-16( 2021).

36. Cai, C., Li, G., Peng, L., Li, J. F. \& Wu, Q. X. Effects of rice-crawfish rotation on soil physicochemical properties in jianghan plain.Acta pedologica sinica56,217-226( 2019)

37. Yi, F. R., Yang, T. J., Zhao, C. Y., Tang, Z. W. \& Fu, Z. Q.. Effects of rice-shrimp co-cultivation on the nutrients in the topsoil layer of paddy field: Based on the empirical analysis of Nan County, Yiyang City.Crop Research33,424-427( 2019).

38. Tian, Y. C. et al., Analysis of soil reducing substance content and economic effect in different sowing times of integrated rice-crayfish system. Hubei Agricultural Sciences59,57-61( 2020).

39. Dong, Y. H. \& Xu, Q. Characteristics and research progress of soil gleying.Progress in Soil Science01,9-14( 1990).

40. Zhou, D. P., Zhu, C. B., Fan, J. Q., Jiang, Z. F. \& Wu, S. H. Microbial Community Structure and Function in Greenhouse Soils of Asparagus.Soils46,1076-1082( 2014).

41. Rogers, B. F., Tate, R. L. \& Tate. Temporal analysis of the soil microbial community along a toposequence in Pineland soils. Soil Biology and Biochemistry33,1389-1401(2001).

42. Yu, C. et al., Efects of long-term straw retention on soil microorganisms under a rice-wheat cropping system.Archives of Microbiology202,19151927( 2020).

43. Zhu, X. X. et al., Effect of rice-crayfish integrated system on soil bacterial community structure and diversity in paddy field.Chinese Journal of Soil Science, ://doi.org/10.19336/j.cnki.trtb.2021012201 ( 2021).

44. Weber, K. P., Grove, J. A., Gehder, M., Anderson, W. A. \& Legge, R. L. Data transformations in the analysis of community-level substrate utilization data from microplates. Journal of Microbiol. Methods 69,461-469( 2007).

45. Zhou, J. \& Lei, T. Review and prospects on methodology and affecting factors of soil microbial diversity. Biodiversity Science15,306-311( 2007).

46. Bao, S. D. Methods for Soil Agricultural and Chemical Analysis30-106(China Agriculture Press, Beijing, 2000).

47. Liu, Z. G. \& Yu, T. R. Studies on oxidation-reduction processes, in paddy soils V. determination of the reducin g compound.Acta pedologica sinica 10,13-28( 1962).

48. Guan, S. Y. Soil Enzyme and Study Method274-313(Agricultural Press, Beijing, 1986).

49. Schutter, M. \& Dick, R. Shift in substrate utilization potential and structure of soil microbial communities in response to carbon substrates. Soil Biology and Biochemistry, 33, 1481-1491 (2001).

\section{Figures}



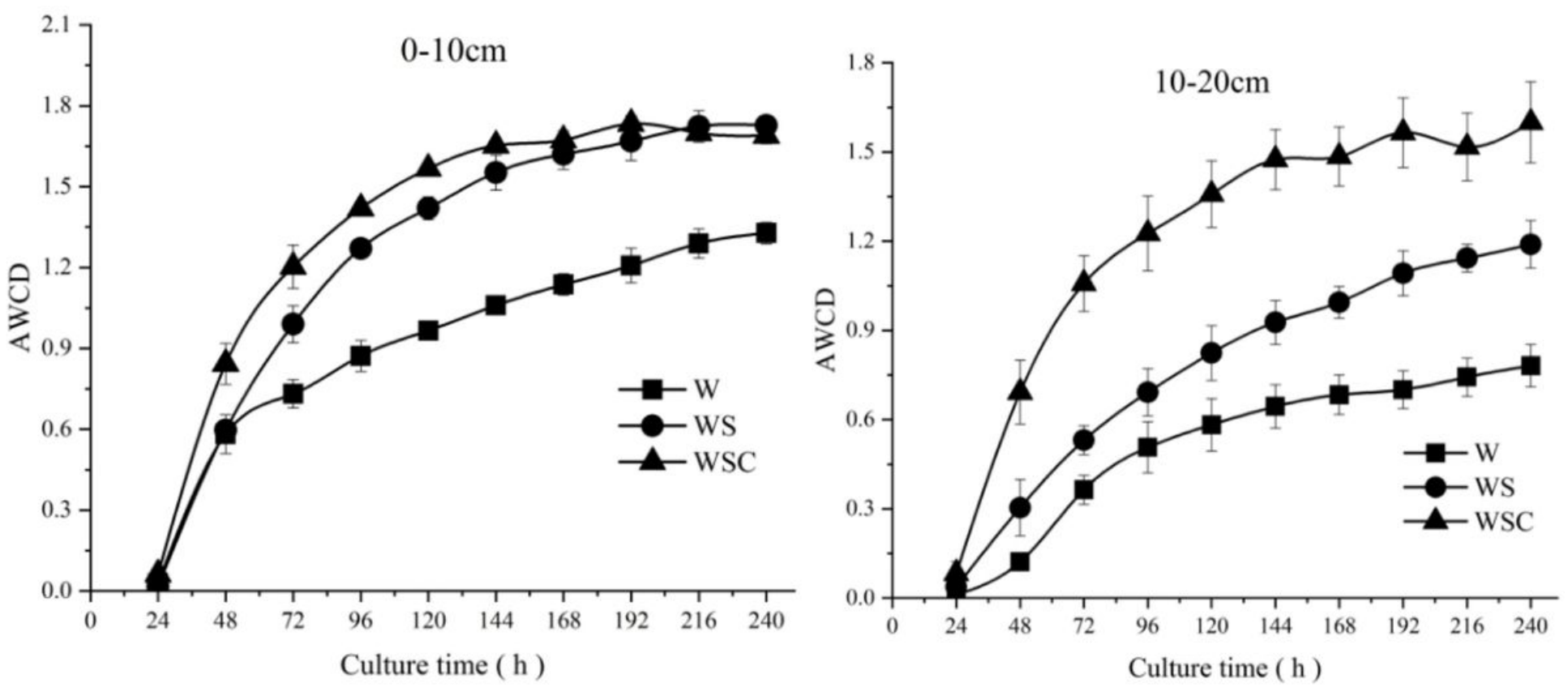

Figure 1

AWCD values of soil microbes in different soil layers
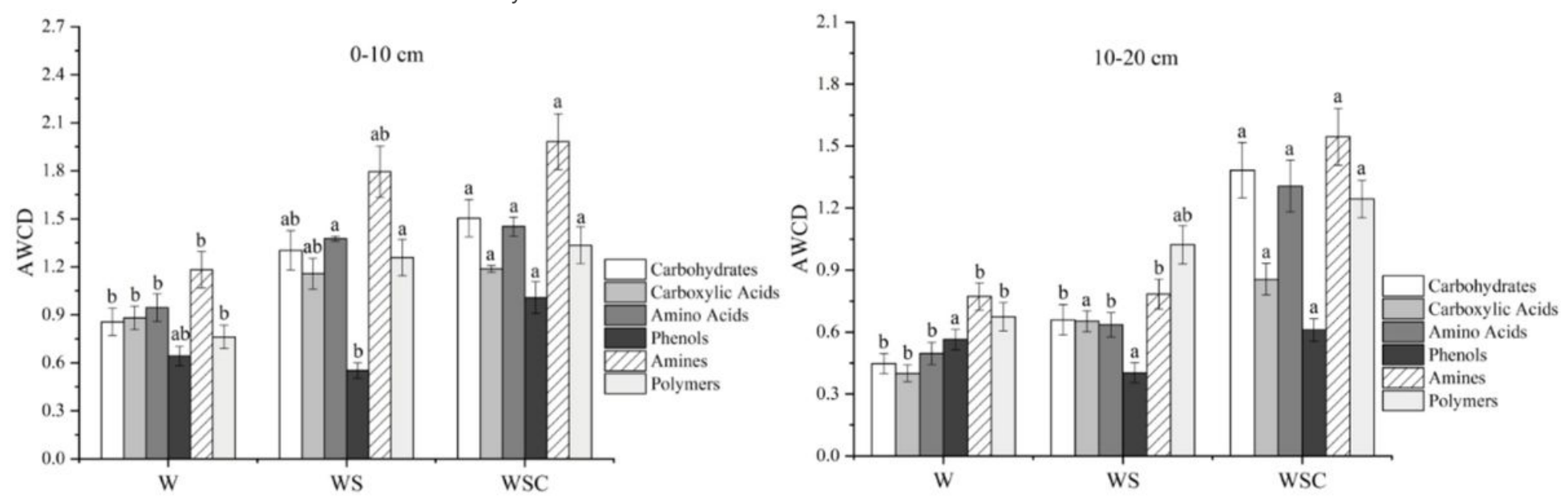

Figure 2

Status of different carbon sources utilized by soil microbes. Means with different letters for the same property in the same soil layer indicate significant differences at $\mathrm{P}<0.05$. 